\title{
実装基板における外観検査の動向
}

\author{
豊島 保典*
}

\section{Trends of Optical Inspection for PWBA}

\author{
Yasunori TOYOSHIMA*
}

*名古屋電機工業株式会社技術開発室（广 490-1294 愛知県あま市篠田面德 29-1）

* Engineerring \& Development Department, Nagoya Electric Works Co., Ltd. (Mentoku 29-1, Shinoda, Ama-shi, Aichi 490-1294)

\section{1. はじめに}

プリント配線板の表面実装は, 部品の微小化やファイン ピッチ化，高多層化など，実装の高密度化が著しい。これ ら基板実装技術の高度化に伴い, 実装基板の検査技術も飛 躍的な進歩を遂げ，普及している。

特に外観検査では，これまで一般的に行われてきた，カ メラと照明を組み合わせた画像処理に加えて, 実装基板面 上の高さ情報を計測する手法 ${ }^{1)}$ や， X 線を用いた手法 ${ }^{2)}$ な

ど, 検査手法も多様化している。

一方で，実装基板においても，使用される製品カテゴリ により, 求められる信頼性や, 検査コストに対する要求が 異なる。

本稿では, 実装基板の生産数量と, 求められる品質（信 頼性）に着目し, 最近の実装基板に対する外観検査の動向 について述べる。

\section{2. 製品のゾーン分けと検査の位置付け}

図 1 は, 生産数量と品質の関わりを示したものである。 横軸は生産数量を, 縦軸は要求される品質を示している。 品質軸の定量的表現は難しいので, 高度な信頼性が必要

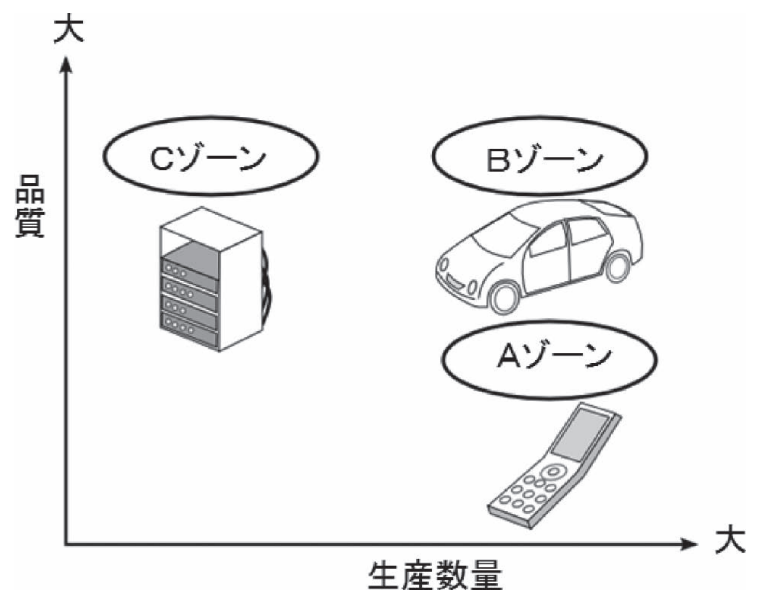

図 1. 生産数量と品質との関係
とされるものと, 比較的高い品質を要求されないものとに 分けた。

2.1 A ゾーン（ボリューム大，品質レベル中）

このゾーンには, 生産数量が多いが, 高度な信頼性は必 要とされない製品群が含まれる。

携带電話, パソコンなどの民生用の電子機器などがこの ゾーンの代表的な製品群である。これらの製品の製造工程 では, 検査コストが製品の競争力に大きく影響するため, あまり厳密な検査を行わず, 最低限の検査により, 品質保 証が行われている場合が多い。

\subsection{B ゾーン（ボリューム大，品質レベル高）}

このゾーンには, 生産数量が多く, かつ高い品質が求め られる製品群が含まれる。

自動車関連の製品などがこのゾーンの代表的な製品群で ある。これらの製品は, 温度, 湿度など使用環境の大きな 変化に対応できる必要があるため, 高度な信頼性が要求さ れている。また, 生産数量も多く, 高速な検査技術も要求 されている。

\subsection{Cゾーン（ボリューム小，品質レベル高）}

このゾーンには, 生産数量は少ないが, 高品質を求めら れるような高価な製品が含まれる。

不具合が起きると被害が甚大になるインフラ系の設備, あるいは, データセンタの中核に使われる高機能計算機, ストレージシステムなどが代表的な製品である。これらの 製品では，検査に費用をかけても高品質な製品を作ること が要求されている。

\section{3. 各ゾーンでの, 外観検査の取組み}

\subsection{A ゾーンにおける外観検査}

このゾーンの製品では, 大量のプリント配線板および実 装基板を高速に検査することが求められている。

検査装置の解析機能を利用して, 工程改善を行い, でき るだけ検査工程を省略する試みも多く見られることがこの ゾーンの特徴になっている。 


\subsection{1 プリント配線板のパターン検査}

最近のプリント配線板では，パターン幅が $10 \mu \mathrm{m} \sim 6 \mu \mathrm{m}$ ライン／スペースに縮小している。

不具合の検査手法としては, 基準パターンを設計データ から生成して比較する手法が主に採用されているが, 一部 では比較基準パターンを持たない手法もある。

3.1.2 印刷はんだペーストの形状検査

印刷はんだペーストの検査は, 三次元計測を行う手法が 最も一般的になっており, 最近では格子縞パターンを投影 して縞パターンの変形から三次元形状を計測する手法が多 くなっている。

計測の死角を低減するために, 複数方向からの格子縞パ ターンを投影する装置もある。

\section{1 .3 はんだバンプの検査}

A ゾーンでは, 高密度化・高機能化のために BGA や CSP が使用されることが多くなり, はんだバンプ検査のニーズ が高まっている。

はんだバンプ検査では, 直接的にはんだバンプの高さを 計測する必要があり，印刷はんだペーストの形状検査と同 様な三次元計測手法が用いられている。

\section{1 .4 実装基板の検査}

実装基板の検査では, 実装部品の検査と, はんだフィ レット形状の検査がある。

両検査共に, 多段照明によるカラー画像から検査する手 法が主に採用されているが，近年では部品の高さを計測し て三次元形状計測する手法も増えてきている。

検査を行うための比較デー夕は, 実物から取得される計 測值を基に作成する方法と, マウンタデータから自動生成 する方法が採用されている。

\subsection{B ゾーンにおける外観検査}

このゾーンに含まれる主な製品である，車載用基板の使 用環境は,

・車両走行中の激しい震動

・エンジンルーム内の高温から寒冷地の極低温

であり, 要求される品質レベルは, 他のゾーンの製品に比 べて非常に高い。

また，不具合発生時には重大事故につながる危険性も大 きい。

このため, このゾーンに使用される実装基板の生産工程 では，工程改善による品質安定化にとどまらず，全数検査 の客先要求に応えるため, より高速・高精度な検査が求め られている。

\section{2 .1 実装基板の外観検査}

車載基板の生産工程では, その信頼性確保のため, ほぼ すべての実装基板について, 部品の有無や取付け方向, は んだフィレット形状などを外観で検査している。

部品の検査については, カメラ画像を用いた画像処理に よる検査が, 今でも最も多く採用されている。
はんだフィレット形状検査については，多段照明による カメラ画像を用いた画像処理による検査（図 2）が行われ ているが，より高精度な検査が可能なスポットレーザー光 をスキャンする手法（図 3）も多く採用されている。

\subsubsection{X 線検査}

B ゾーンに含まれる車載用の実装基板でも，高密度化が 進んでおり，BGA/CSP の使用が急速に普及し始めている。

これらの実装方法では，はんだ接合部を直接観察するこ とができないため，外観検査を行うことができない。この ことから X 線による検査のニーズが非常に高まっている。

はんだの未接合やショートの検出はもちろんのこと，は んだ接合の信頼性につながる，はんだ接合部のボイド検査 の必要性が指摘されている。

$\mathrm{X}$ 線検査装置が登場したころは, 単純な $\mathrm{X}$ 線透視画像に よる二次元検査が主流だった。眓 4 は，X 線透視画像によ るはんだ接合部内のボイド検出画像の例である。

しかしながら, 単純な X 線透視画像では, 両面実装基板 の裏面部品の影響や, 部品内蔵基板の出現などにより, 部 分的に検査ができない場合があり，現在では X 線 CT 手法 による三次元検査に注目が集まっている。図 5 は, X 線 CT 画像による，はんだ接合部の未接合検出画像の例である。

このように，X線による検査の必要性については十分に 認知されている。しかし, 検査性能・検査スピード・装置 コストなどの点で, プリント配線板実装メーカが求めてい る性能をすべて満足するX 線検査装置は，まだ現れていな い。このため, いずれかの項目を犠牲にして品質を確保し ているのが実情である。

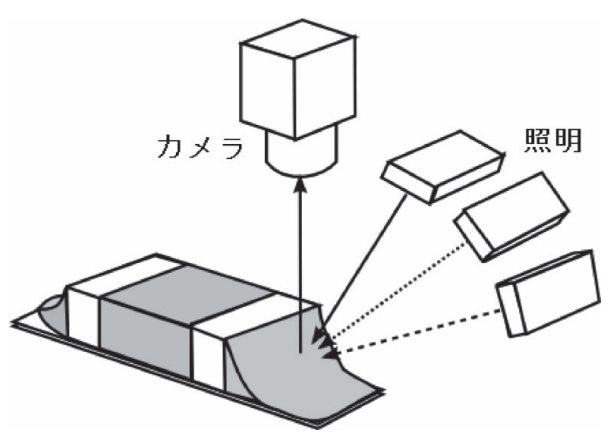

図 2. 多段照明を用いる手法

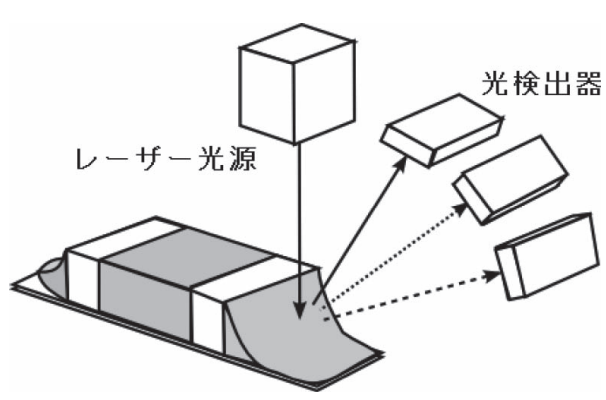

図 3. スポットレーザー光を用いる手法 


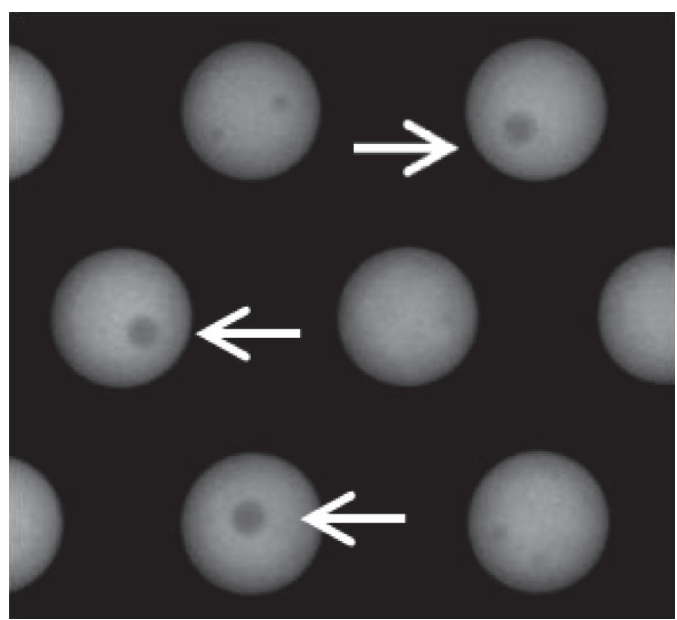

図 4. X 線透視画像（矢印はボイド）

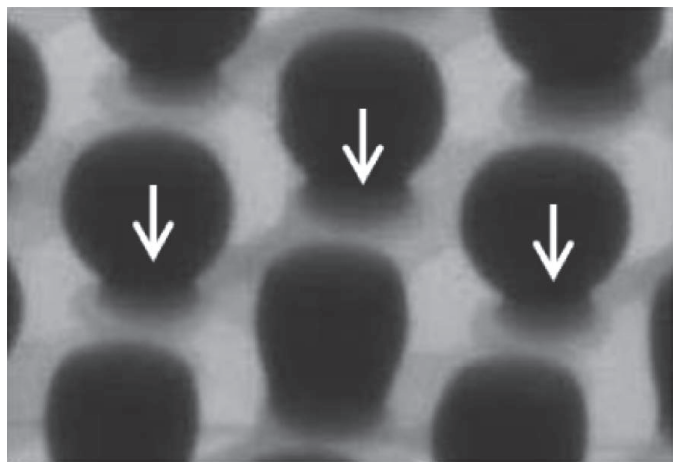

図 5. X 線 CT 画像（矢印は未接合）

$\mathrm{X}$ 線検查装置メーカでは, マイクロフォーカスやナノ フォーカスと呼ばれる発生源サイズが微少な X 線源を使用 して画像の鮮明度を上げる工夫や, 新たな高速三次元画像 解析手法などの新技術開発などを行っているが，より高速 化と低コスト化を進める技術的なブレークスルーが期待さ れている。

\subsection{Cゾーンにおける外観検査}

このゾーンに含まれる製品は，付加価值が高いものが多 く, 高い品質レベルが求められている。

このため，このゾーンの製品群では，外観検査装置で検 出した不具合に対して, 人による再チェックを行い, 実際 の不具合箇所を修正して製品を完成させるケースも多く見 受けられる。

したがって，外観検査装置には，Bゾーンの製品と同じ 要求に加えて, 検出した不具合箇所を作業者にわかりやす く指示する機能が重要になる。

3.3.1 目視確認支援システム

多くの外観検査装置には, 目視確認支援システムが用意 されている。

検査装置からの検査結果を管理し，その中に含まれてい る画像から, 最終目視チェックする機能や, 製品の品質卜 レーサビリティを管理する機能などを備えているものがほ

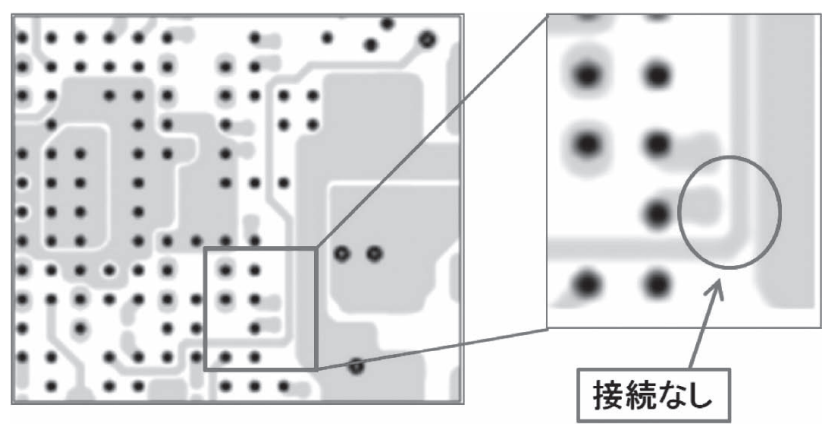

図 6. CAD による内層パターン図

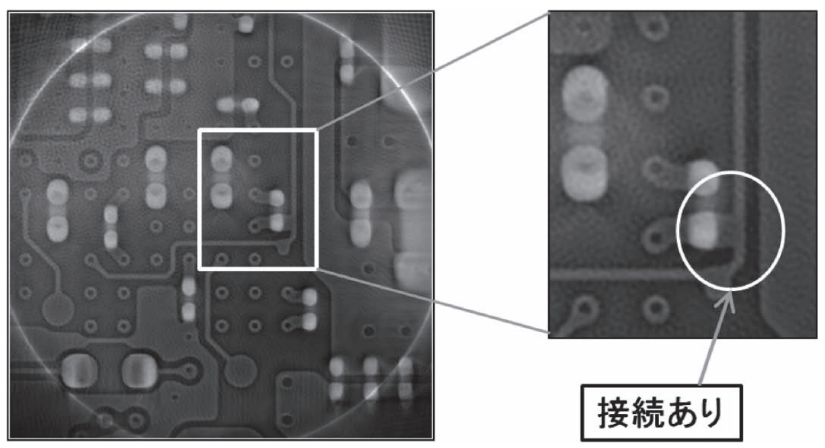

図 7. 内層パターンの X 線 CT 画像

\section{とんどである。}

これらの中には，実際の基板をセットし，検査装置が検 出した不具合箇所データに基づいてカメラ位置に移動し, 拡大画像や斜視画像によって, 作業者の目視チェックを支 援する装置も多く見られる。

\subsection{2 複数の装置連携による解析例}

特定のゾーンの製品に限ったことではないが，複数の検 査装置が連携することで，スムーズな不具合検証と対策が 可能になる場合がある。

以下の例は，プリント配線板設計における不具合解析の 実例である。

この例は，実装後に行ったインサーキットテストで， ショート不具合が検出された。CAD データ，ネットリスト (接続情報）や，作画パターンデータ上に不具合は見つけら れなかった（図 6)。

そこで，まずインサーキットテストの不具合情報から， ショートが疑われる内層パターンの領域を推定し, 続いて この領域を X 線 CT 装置で観察した結果, 図 7 のように, CAD データにはない接続（ショート）が確認することがで きた。

このように, ファンクション検査の結果と, CAD データ とを連携させることで, 不具合が疑われる部分を推定する ことができ，X 線 CT 検查装置による効率的な不具合検証 が可能になる。 


\section{4. まとめ}

実装基板における外観検査については，対象となる製品 により, 求められる機能や品質レベルが異なる。このよう な多様なニーズを, 1 台の検査装置で実現することは, 性 能面やコス卜面で，かなり難しい状況になっている。

最近では, 高価な多機能の検查装置よりも, 優先される 要求項目に対して, 最適な検查手法を持つ単機能の検查装 置を選択し, さらに組合せることで, 製品に必要な検査品 質を確保するという考え方が, 見られるようになってき た。このような構成の検查装置の方が, 扱いやすく, 低コ ス卜になる場合が少なくない。

外観検查装置には，これまで 1 台ですべて対応できる高 機能検查装置が求められてきた。しかしこれからは, 単機 能でも特徴あるシンプルな検査機能を低価格で提供する検 查装置が提供されることを期待したい。

これらの単機能検査装置を組合せて, 製品に合った実装 基板の品質を確保するための選択肢が広がるような検査工
程を構築することが, 多様なニーズに応える方法の $1 つ に$ なると確信する。

(2013.9.5- 受理)

\section{文献}

1）松村康行：“進化する外観検查技術,”エレクトロニクス実 装技術，Vol. 29, No. 2, pp. 12-15, 2013

2）豊島保典: “高密度実装基板外観検查の動向,” エレクトロ ニクス実装学会誌, Vol. 14, No. 2, pp. 90-93, 2011

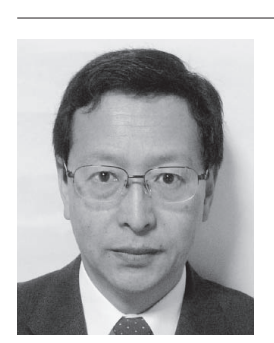

著者紹介

豊島保典（とよしま やすのり）

1983 年 名古屋電機工業株式会社 入社。

実装基板の外観検查装置開発に従事。

現在，技術開発室 室長。 